\title{
GERILYA ALOR MELAWAN SAMPAH PLASTIK LAUT, PENGELOLAAN DOMESTIK DAN BERBAGAI PERJUMPAAN
}

\author{
Klara Puspa Indrawati ${ }^{1}$, Antonius Tan ${ }^{2}$, dan Mekar Sari Suteja ${ }^{3}$ \\ ${ }^{1}$ Program Studi Arsitektur, Universitas Tarumanagara Jakarta \\ ${ }^{2}$ Arsitek, Jakarta \\ ${ }^{3}$ Program Studi Arsitektur, Universitas Tarumanagara Jakarta
}

\begin{abstract}
Abstrak
Beberapa tahun terakhir, Kabupaten Alor dihadapkan pada pola konsumsi baru yang berakibat pada melonjaknya jumlah sampah plastik. Pemerintah setempat belum memiliki strategi pengelolaan sampah plastik di level domestik maupun di level kabupaten yang memadai. Saat ini sampah plastik telah mencemari laut dan pesisir, padahal pariwisata bawah laut sedang berkembang di berbagai pesisir Alor hari ini. Jenis pariwisata ini membutuhkan situasi ekosistem pesisir yang sehat, namun aktivitas bisnis penginapan dan penyelaman yang tidak diatur oleh regulasi pemerintah juga berpotensi menjadi penghasil sampah plastik. Perjumpaan warga lokal dengan gelombang tren pariwisata bawah laut ini menghasilkan kesadaran untuk membersihkan laut dan pesisir dari polusi sampah plastik. Para pemerhati lingkungan Alor bekerja secara kolektif dan menghasilkan progres. Tim PKM Untar berkesempatan turut berkontribusi melalui workshop kolaboratif dengan jejaring "Plastic Free Ocean Network” (PFON-Alor) untuk anak-anak di pesisir Kadelang dan Alor Kecil demi membangunkan gema kesadaran yang semakin besar dan semakin awal di level domestik. Anak-anak merupakan agen perubahan yang diharapkan mampu mendorong perilaku mereduksi maupun mengelola sampah plastik secara berkelanjutan dalam sebuah keluarga. Workshop untuk anak yang telah diselenggarakan di dua desa pesisir menunjukkan kebutuhan program edukasi informal tentang sampah plastik bagi warga Alor. Seluruh gerilya melawan sampah plastik ini dilatarbelakangi oleh kuatnya ikatan historis, spiritual, dan kultural warga Alor dengan laut yang mengelilinginya.
\end{abstract}

Kata kunci: domestik, laut, gerilya kolektif, pariwisata, sampah plastik

\section{PENDAHULUAN}

Di awal tahun 2019, WWF Indonesia mengemukakan informasi dari sebuah pendataan sampah di sebuah pesisir dekat pusat kota Kalabahi sepanjang akhir tahun 2018 yang menunjukkan $76 \%$ dari keseluruhan total sampah terbuat dari plastik. Para peneliti lokal dan penggiat lingkungan juga mengamati adanya tren peningkatan sampah plastik yang signifikan di Kabupaten Alor selama beberapa tahun terakhir, sementara itu upaya untuk memakai kembali maupun mendaur ulang masih sangat rendah. Hari ini, komitmen para pemerhati lingkungan Alor beranjak serius: jejaring "Plastic Free Ocean" diinisiasi oleh WWF Indonesia dan Universitas Tribuana Kalabahi dengan menggandeng berbagai komunitas lokal demi mendesak aksi nyata. Misi mereka berfokus pada terwujudnya ekosistem pesisir berkelanjutan sebagai penjamin kesejahteraan ekologis, ekonomi, dan sosial warga Alor.

Laut telah lama menjelma menjadi sumber kehidupan dan penghidupan warga Alor yang juga diyakini sebagai lokasi tahta para leluhur serta sebagai akses utama berbagai perjumpaan dengan kehidupan di luar Alor. Perjumpaan yang membawa perkembangan pengetahuan dan ekonomi bagi warga lokal. Keterikatan antara kehidupan darat dan laut telah menjadi nafas utama rumah tangga atau pengelolaan domestik dengan mengikuti ritme siklus musim hujan dan kering. Sepanjang bulan April hingga Oktober, warga lokal akan memburu berbagai tangkapan laut. Sementara sepanjang bulan Oktober hingga April, mereka akan bertani. Ritme pengelolaan domestik yang terus berulang ini telah menjamin kehidupan warga dari generasi ke generasi.

Warga lokal memahami dengan baik potensi setiap material lokal, sehingga berbagai perkakas rumah tangga, seperti wadah dari daun lontar atau anyaman bambu, dapat dibuat sendiri. Bekas konsumsi pangan dan rumah tangga yang tidak terpakai semuanya bersifat organik. Namun, sejak sistem ekonomi uang menawarkan berbagai kemudahan baru, warga memilih untuk membeli 
hampir semua kebutuhan. Produk industrial, termasuk perabotan domestik, yang didistribusikan di Alor berkemasan plastik atau berbahan dasar plastik. Pola konsumsi baru ini berujung pada melonjaknya jumlah sampah plastik di level domestik.

Di saat pemerintah lokal belum memiliki perencanaan pengelolaan sampah domestik yang baik, sejumlah warga mengalihkan sampah mereka ke lahan-lahan kosong, saluran drainase, bahkan ke laut dan wilayah pesisir. Situasi semakin kritis ketika mengingat Kabupaten Alor memiliki kondisi geografis berupa kepulauan yang perbukitannya langsung dikelilingi laut. Ibukota Kabupaten, Kalabahi, menjadi satu-satunya area datar terluas. Warga membangun rumah mereka dalam radius 1-3 km dari garis pantai. Jarak yang terhitung dekat ini akan memudahkan sampah plastik dari area pemukiman mencapai laut.

Sejak nama Alor terpublikasi luas pertama kali melalui buku panduan pariwisata internasional "Lonely Planet" pada tahun 2003 silam, popularitas kabupaten ini sebagai lokasi penyelaman berkelas dunia (Witton et al., 2003) kian meningkat. Beberapa pendatang dari Eropa dan Amerika yang pernah melakukan penyelaman di Alor memutuskan untuk mendirikan usaha penginapan dan penyelaman di beberapa titik pantai di seluruh Kabupaten Alor. Di sisi lain, tata ruang dan wilayah Kabupaten Alor, yang masih belum sepenuhnya ditentukan, dipublikasi, dan diterapkan, tidak dapat melindungi kerentanan ekosistem laut dan pesisir terhadap kerusakan akibat pembangunan fisik semacam fasilitas-fasilitas pariwisata.

Pada saat yang bersamaan, beberapa tokoh lokal mulai membangun kesadaran kolektif tentang beraneka isu sosial dan ekologis terkini dan terdorong untuk bergerak dalam komunitaskomunitas. Saat isu pencemaran lingkungan karena sampah plastik mengemuka, mereka berbagi keresahan yang serupa dan memutuskan untuk berjejaring. Banyak warga lokal saat ini, yang baik secara individual maupun kelompok, telah sukarela terlibat aktif dalam "Plastic Free Ocean Network" (PFON) sambil saling kembali membangun memori kolektif tentang ikatan mendalam kehidupan manusia Alor dengan laut yang harus dialihserahkan pada keturunan mereka, para penghuni masa depan.

Tulisan ini akan mendiskusikan kekuatan dari gerakan komunitas-komunitas di Alor dalam menanggulangi masalah pencemaran plastik yang ternyata menggambarkan tautan historis, spiritual, dan kultural mereka terhadap laut. Berbagai gerakan yang telah bergulir dengan misi membangkitkan kesadaran ekologis pada level domestik juga turut diuraikan. Tim PKM juga akan mendiskusikan isu yang muncul dari perjumpaan warga lokal dengan sebuah situasi baru berupa pariwisata bawah laut, terutama mengenai keberlanjutan lingkungan yang dihubungkan dengan langkah pemerintah dalam melindungi ekosistem laut dan pesisir sambil turut menyertakan pendapat warga dan beberapa pemilik usaha penginapan dan penyelaman mengenai isu sampah plastik yang telah mencemari pesisir dan laut Alor.

\section{METODE PELAKSANAAN PKM}

Tim PKM Untar menggunakan studi etnografis sebagai pendekatan untuk mengumpulkan data dan menghasilkan temuan, terutama melalui dialog intens dengan beberapa penggiat lingkungan yang juga tergabung dalam "Plastic Free Ocean Network" (PFON-Alor). Tim PKM juga mewawancarai beberapa pemilik usaha penginapan dan penyelaman. Untuk dapat memahami lebih dalam mengenai isu sampah plastik, terutama di sekitar area pesisir, dua event kolaboratif diselenggarakan oleh Tim PKM dari Program Studi Arsitektur Untar bersama dengan tokoh-tokoh lokal yang berupa workshop untuk anak-anak di dua pemukiman pesisir di Pantai Kadelang dan Pantai Alor Kecil. 
Workshop ini berfungsi sebagai medium bagi Tim PKM maupun anak-anak Alor untuk membangun konsepsi keterikatan ekologis antara generasi masa depan dengan kelestarian ekosistem laut dan pesisir di sekitar pemukiman warga. Tim PKM menggunakan studi literatur sebagai pendekatan sekunder yang lebih banyak berasal dari dokumentasi studi para penggiat lokal selama memperjuangkan kelestarian laut Alor terhadap pencemaran sampah plastik yang turut menerangkan kompleksitas masalah, rencana penanganan dari pemerintah lokal, serta jangkauan progres yang telah dicapai dari gerakan-gerakan kolektif yang diinisiasi warga lokal. Sebuah artikel jurnal yang pernah ditulis Ketua Tim PKM pada tahun 2016 tentang nilai sosial, politik, budaya, serta ekonomi laut dalam sejarah kehidupan warga Alor menjadi referensi penting untuk mengungkap motivasi di balik gerilya kolektif pelestarian lingkungan melawan sampah plastik di Alor hari ini.

\section{HASIL \& PEMBAHASAN}

\section{Laut, Rumah Tangga, dan Munculnya Masalah Sampah Plastik}

Dari waktu ke waktu, laut selalu berperan sebagai elemen produktif pembentuk kehidupan warga di Kabupaten Alor, Provinsi NTT. Sejumlah dongeng dan kisah mitologi setempat menggambarkan laut sebagai sebuah dunia misterius yang menjadi tempat asal nenek moyang. Warga Alor yakin bahwa laut menyimpan kekuatan sakral untuk menciptakan kehidupan penduduk di darat dan menjamin keberlangsungan hidup mereka. Kisah-kisah ini berkembang di berbagai kelompok etnis keturunan dari etnis penghuni asli Alor maupun keturunan dari campuran kelompok etnis dari luar Alor, seperti Jawa, Cina, dan Makassar yang mencapai Alor melalui jalur laut (Indrawati, 2016).

Dalam studinya, Bessie dan Ariyogagutama (2012) menemukan 4.414 dari 181.913 total penduduk berprofesi sebagai nelayan dan usaha perikanan berperan krusial dalam perkembangan ekonomi di Kabupaten Alor. Mereka juga menyebutkan bahwa 59,43\% dari seluruh desa di Alor merupakan desa pesisir (Bessie \& Ariyogagautama, 2012). Wawancara yang kami lakukan dengan beberapa nelayan di beberapa lokasi juga mengungkap fakta menarik. Nelayan Alor, biasanya bergender laki-laki, telah membangun model pengetahuan khas untuk mengenali perilaku laut dan hewanhewan di dalamnya yakni dengan menggunakan tanda-tanda alam yang dapat ditangkap oleh panca indera mereka. Penduduk yang tinggal di pemukiman pesisir meyakini nenek moyang mereka datang dari kedalaman laut, sehingga pada waktu-waktu tertentu mereka masih menyelenggarakan ritual penghormatan dan pengucapan syukur sebelum melaut. Misalnya masyarakat etnis Manglolong yang masih melakukan "Puhari", sebuah ritual melarung persembahan bagi 7 penjaga laut sambil menyampaikan doa untuk terkabulnya sebuah permohonan (Sere, 2016). Relasi yang dibangun antara warga pesisir dan laut telah melampaui nilai pragmatis (Indrawati, 2016).

Jika diamati secara spasial, setiap desa di Kabupaten Alor memiliki setidaknya sebuah altar batu. Altar ini selalu menjadi titik sakral pusat ritual yang terdiri dari dua bagian utama: sebuah platform yang menandai aksis kosmik horisontal dan sebuah tiang kayu atau pohon yang tertanam di atas platform sebagai penanda aksis vertikal. Kedua bagian ini juga mewakili penyatuan unsur maskulin berupa tiang atau pohon dengan unsur feminin berupa platform batu (Waterson, 1990). Altar dapat diduga berperan sebagai penanda axis mundi atau titik awal penciptaan kehidupan di sebuah tempat. Kelompok etnis Manglolong yang menghuni desa Alor Kecil dan Pulau Kepa memiliki altar batu yang berlokasi di sebuah area pantai sakral "Haribatang" di Pulau Kepa. Lokasi altar (Gambar 1) diyakini sebagai lokasi perkawinan penjaga laut "Buiharipanatu" dan penjaga daratan "Muji Mujemo" sebagai dua leluhur masyarakat Manglolong (Sere, 2016). 
Penduduk Kabupaten Alor menghuni dua macam area pemukiman, di dataran tinggi pada daerah perbukitan serta pegunungan dan di dataran rendah sekitar pantai. Kedua kondisi lingkungan ini mendorong cara bertahan hidup yang secara kontekstual berbeda. Penduduk di dataran tinggi menanam berbagai jenis bahan pangan seperti sayur, buah, kopi, singkong, dan umbi-umbian lainnya. Sementara itu masyarakat di pinggir pantai menangkap ikan dan hewan laut lain sambil mengelola beberapa tanaman yang bisa tumbuh di ladang dataran rendah, seperti jagung. Menjelang pukul 6.00 pagi, kapal-kapal nelayan mulai menepi dan tangkapan berupa ikan, udang, cumi, dan gurita akan dibawa tengkulak yang dalam bahasa lokal disebut papalele ke pasar-pasar di Kalabahi.

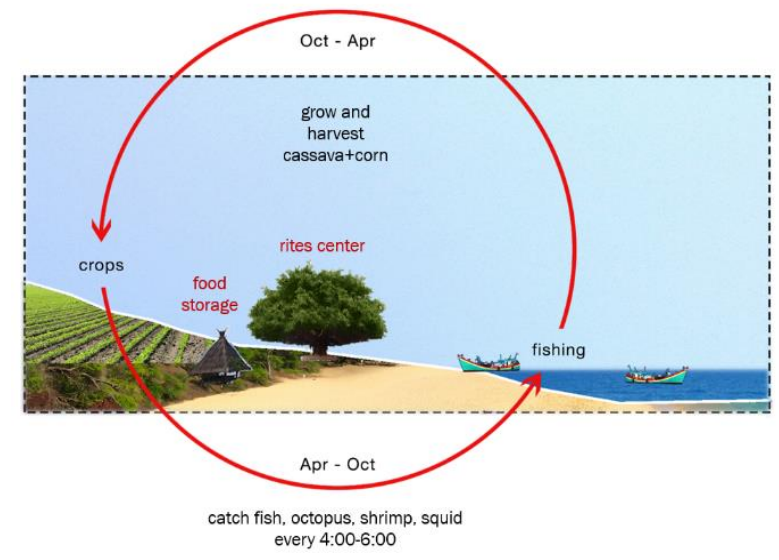

Gambar 1. Siklus Pemenuhan Pangan Natural di Pemukiman Pesisir (Sumber: Klara Puspa Indrawati, 2016)

Saat fasilitas gedung sekolah belum memadai dan bersekolah belum menjadi prioritas sebelum era 1980an, anak laki-laki yang tinggal di sekitar pantai sudah menguasai teknik menangkap ikan dengan cara menyelam di laut dangkal sejak usia 8 tahun. Mereka berkewajiban membantu orang tua menangkap ikan sepanjang malam hingga subuh dan mengantarkannya ke pasar. Tokoh adat Manglolong, Sere (2016), menceritakan pengalamannya saat berusia 12 tahun. Ia tak melanjutkan sekolah dan setiap harinya setelah membantu menangkap ikan, ia harus berjalan kaki sejauh 14 km dari Alor kecil ke Kalabahi untuk mengantar ikan ke pasar. Setelah sekolah dasar dan menengah pertama didirikan, anak-anak mulai diarahkan untuk bersekolah oleh orang tua. Pada tahun 2014, gedung SMA pertama di Desa Alor Kecil didirikan. Kini, anak-anak yang tinggal di sekitar pesisir menjadikan pantai dan laut sebagai ruang bermain di sore hari tanpa adanya keharusan membawa pulang tangkapan.

Laut kini membawa perjumpaan baru bagi warga lokal, bukan dengan sumber makanan dari laut melainkan dengan para turis yang memburu keindahan terumbu karang. Semenjak keindahan bawah laut Alor menjadi sorotan "Lonely Planet" pada 2003, pariwisata diving mulai membuka potensi ekonomi baru bagi warga lokal. Alor memiliki 43 titik penyelaman dengan periode penyelaman terbaik sepanjang bulan Maret sampai Desember (Dinas Pariwisata Kab. Alor, 2016). Pada tahun 2016, Kabupaten Alor meraih gelar "The Most Popular Diving Spot in Indonesia" dari Anugerah Pesona Indonesia. Saat ini Dinas Pariwisata Kab. Alor mencatat terdapat 8 usaha penginapan dan penyelaman yang dimiliki oleh pendatang dari Eropa dan Amerika, kecuali "Air Dive" yang didirikan pada tahun 2016 oleh sekelompok pemuda Indonesia dari Jakarta (Willy, 2019). Saat ini pariwisata laut Alor juga diramaikan dengan kemunculan dugong atau ikan duyung di Pulau Sika. Dugong merupakan hewan langka yang dilindungi. 
Sejumlah kecil warga lokal menjadi pekerja pada bisnis-bisnis penginapan dan penyelaman, yang pria menjadi pengendali kapal, staf pendamping penyelaman, atau staf pemeliharaan alat-alat, sementara para wanita membantu menyiapkan makanan dan memelihara kebersihan serta kerapihan akomodasi. Namun, masih sedikit di antara warga Alor yang memegang sertifikiasi penyelam yang programnya harus ditempuh di Pulau Jawa atau Bali dan menghabiskan dana besar. Warga Alor yang sudah terlibat dalam bisnis penyelaman semakin memahami betapa berharganya menjaga kesehatan terumbu karang di laut Alor. Para staf laki-laki yang juga bekerja paruh waktu sebagai nelayan mulai secara ketat menerapkan metode penangkapan ikan dan hewan laut yang non-destruktif. Empati semacam ini penting dimiliki oleh seluruh warga Alor sebab degradasi lingkungan pesisir dan laut akan menghasilkan krisis eksistensial, sosio-kultural, dan ekologis bagi warga yang telah membangun ikatan historis bahkan spiritual dengan laut (Indrawati, 2016).

Pada beberapa daerah pesisir, hasil tangkapan pertama-tama akan dijual dan bila bersisa akan dikonsumsi, seperti di Desa Alor Kecil. Melalui hasil penjualan tangkapan laut, penduduk Alor Kecil perlahan mulai tidak menggantungkan kebutuhan karbohidrat dari menanam pangan. Uang yang mereka peroleh memudahkan memperoleh beras atau jagung setiap saat. Dengan pola pemenuhan pangan yang baru ini, penduduk Alor Kecil tak lagi sepenuhnya mengikuti siklus natural dua musim dalam pengelolaan pangan dari darat dan laut. Sementara itu, masalah baru mulai muncul. Barang-barang kebutuhan dan bahan pangan yang dijual tersebut merupakan produk industrial yang didistribusikan dalam kemasan. Berbagai kebutuhan lain, seperti kudapan ringan, perlengkapan mandi, rokok, kopi bubuk kemasan, mie instan, air mineral seluruhnya dijual terkemas dalam plastik lunak maupun plastik keras yang sulit terurai. Saat dibeli pun, biasanya penjual akan memasukkan barang ke dalam kantung plastik.

Portal berita BBC menyatakan 70\% sampah di Indonesia dihasilkan dari aktivitas rumah tangga (bbc.com, 2018). Dalam presentasi di bulan Februari 2019, WWF Indonesia menjelaskan bahwa sejak 2015 Indonesia mendapat peringkat ke 2 setelah Tiongkok sebagai penghasil sampah plastik terbanyak di dunia (WWF Indonesia, 2019). WWF Indonesia juga mengutip Kementrian Lingkungan Hidup yang menyatakan $80 \%$ sampah di laut datang dari darat. Walaupun pemerintah lokal telah membuat rancangan jadwal pembersihan dan pengangkutan setiap pukul 5.30-7.00 pagi dan 15.00-16.00 sore dengan 315 pekerja di 5 rute, nyatanya praktek di lapangan masih jauh dari ideal, belum lagi persoalan dari Tempat Pembuangan Akhir (TPA) yang masih bersifat open dumping dengan pembakaran sampah setelah mencapai kuantitas tertentu. Alokasi anggaran pemerintah lokal untuk fasilitas pengelolaan sampah masih kurang dari 1\% (Kolly, 2019). Di sisi lain, kesadaran warga tentang pengelolaan sampah di level domestik juga masih rendah. Peneliti lokal, Faryda Kolly (2019), mencatat hanya $11 \%$ penduduk yang memiliki wadah sampah di rumah dan $98,8 \%$ dari seluruh penduduk belum memilah sampah rumah tangganya. Sejumlah 35\% penduduk membakar sampah mereka.

Plastik membutuhkan waktu puluhan hingga ratusan tahun untuk dapat terurai di alam. Jika terurai di dalam tanah atau laut, plastik akan berubah menjadi mikroplastik yang berbahaya bagi makhluk hidup karena bersifat karsinogenik (PFON, 2019). Berbagai resiko kesehatan akan dialami jika salah mengelola sampah plastik. Manusia yang menghirup udara yang tercemar hasil bakaran sampah plastik berupa dioksin akan rentan terkena kanker, pembengkakan hati, dan depresi. Hewan laut seringkali mengira sampah plastik sebagai makanan. Lama-kelamaan hewan tersebut akan mati karena plastik tak dapat dicerna. Beberapa hewan laut tak mampu bergerak karena terjerat tumpukan plastik. Atau yang cukup populer di sosial media, seekor penyu yang menderita karena hidungnya tersumbat sedotan plastik. Cairan yang dihasilkan dari proses dekomposisi 
sampah juga dapat mengandung mikroba patogen, logam berat, dan zat berbahaya lain yang berpotensi mencemari tanah, air tanah, laut, dan udara (Wardi, 2011).

\section{Perjumpaan Baru di Laut: Pariwisata Penyelaman dan Turis Internasional}

Ketika diving mulai digandrungi para traveler internasional, nama Alor mencuat sebagai salah satu tujuan. Namun, jumlah turis yang datang dalam jumlah besar masih jarang terjadi. "La Petite Kepa", "Dive Alor Dive", "Alor Dive”, “Alor Divers", “Alami Alor”, “Alor Nusa Dive”, "Little Turtle" adalah 7 usaha penginapan dan penyelaman yang didirikan oleh pendatang Eropa dan Amerika. Mereka terpesona dengan alam bawah laut Alor dan akhirnya membuka usaha pariwisata. Willy (2019), salah satu pemilik "Air Dive" yang merupakan satu-satunya usaha diving yang didirikan oleh warga negara Indoenesia, bercerita bahwa slogan "green" kian marak dipopulerkan oleh para pengelola usaha penginapan dan penyelaman untuk menarik perhatian turis. Walaupun nyatanya, tak seluruh aktivitas dalam pengelolaan pariwisata mereka bersifat sustainable.

Dalam penelitiannya di Desa Alor Kecil pada 2016, ketua tim PKM menemukan bahwa bisnis penyelaman yang didirikan pertama kali di Alor melabel penginapan mereka sebagai "ecobungalow" di Pulau Kepa (Indrawati, 2016). Pemiliknya menyebut diri melakukan penghematan penggunaan energi dengan mematikan listrik di malam hari, menghemat air, dan bersikap tegas kontra terhadap metode penangkapan ikan yang merusak terumbu karang. Saat diteliti lebih jauh, Pulau Kepa merupakan pulau yang belum dialiri instalasi listrik PLN dan pada musim kering hanya memiliki sedikit sekali air. Warga Alor di Pulau Kepa mendapat bantuan panel surya dari pemerintah untuk pasokan listrik malam hari dan mereka rutin mengambil air dari sebuah sumur di Alor Kecil. Dengan kata lain, terlepas dari slogan "green", pengelola penginapan di Pulau Kepa memang harus hemat energi dan air sebagai strategi menjalankan bisnis.

Isu peningkatan sampah plastik juga telah mendorong para pengelola bisnis penginapan dan penyelaman untuk mulai memilah sampah, di antaranya "Alami Alor" dan "La Petite Kepa" (Kolly, 2019). Kennedy Takalao (2019), seorang diving guide asal Manado yang juga akan mendirikan penginapan di Pantai Syahbanjar menuturkan bahwa ia memberi perhatian lebih pada kelestarian bakau dan terumbu karang dengan merancang penginapan pinggir pantainya menggunakan prinsip permaculture. Prinsip ini juga meniadakan penggunaan bahan-bahan tidak ramah lingkungan, termasuk plastik. Limbah plastik yang masuk ke laut juga akan merusak kesehatan terumbu karang dengan cara menghalangi akses cahaya matahari yang dibutuhkan untuk proses fotosintesis terumbu karang (bbc.com, 2018).

Saat ini, pemerintah belum memiliki perencanaan dan peraturan yang jelas tentang pariwisata pesisir dan bawah laut di Kabupaten Alor. Dalam presentasi yang disampaikan Satuan Kerja Pengembangan Sistem Penyehatan Lingkungan Pemukiman Provinsi NTT (2018) disebutkan bahwa regulasi pemerintah daerah selama ini belum mencakup teknis penanganan sampah, seperti tugas, wewenang, dan tanggung jawab pemerintah lokal, masyarakat umum, dan pelaku usaha terkait pengelolaan sampah. Sanksi konkret juga belum diterapkan. Ketiadaan peraturan ini menggambarkan tidak adanya upaya perlindungan bagi kelestarian laut dan pesisir dari polusi sampah plastik. Padahal saat ini laut dan pesisir menjadi sasaran paling menggiurkan untuk pembangunan penginapan dan berbagai fasilitas pariwisata yang tentu akan sangat berpotensi menjadi awal produksi sampah plastik.

Pada tahun 2015, pemerintah daerah telah mengeluarkan peraturan terkait sanksi 50 juta rupiah bagi pihak yang membuang sampah tidak pada tempatnya. Selanjutnya pada tahun 2018, 
dikeluarkan sebuah peraturan pengelolaan sampah rumah tangga tanpa adanya uraian teknis. Kedua peraturan ini masih nihil dalam aplikasi dan tidak bermanfaat besar untuk mengatasi isu sampah plastik. Keterangan dari Ir. Zet Malelak, Direktur Pertanian Lahan Kering Universitas Cendana Kupang, yang dimuat oleh Tribuana Pos, turut menguatkan keprihatinan: pengelolaan sampah di Kabupaten Alor termasuk yang terburuk di seluruh NTT (tribuanapos.com, 2018).

\section{Gerilya Melawan Sampah Plastik}

WWF Indonesia (2019) juga menjelaskan hasil pendataan sampah oleh International Coastal Cleanup Report tahun 2017 yang menghasilkan 10 jenis sampah terbanyak di dunia. Tujuh jenis di antaranya merupakan sampah plastik. Sementara itu, Presiden Joko Widodo berkomitmen untuk mengurangi 75\% sampah plastik di laut hingga tahun 2025 (WWF Indonesia, 2019). Untuk mencapai tujuan ini, berbagai upaya harus mulai dikejar. Mulai dari pendataan sampah, penerapan 3R (Reduce, Reuse, Recycle), pemilahan sampah, pembuatan regulasi bagi masyarakat umum dan pelaku usaha, pembersihan area pesisir, serta kampanye dan sosialisasi publik tentang penanggulangan sampah plastik.

Pada tahun 2013, pemimpin Kelurahan Mutiara, Elyas Asamau mulai merasa khawatir dengan sampah plastik yang diamatinya berserakan di saluran drainase, di sepanjang jalan raya, di sekitar pemukiman, di sekitar area bakau, dan di pesisir pantai. Ia segera menggagas program Bank Sampah yang mengadopsi pendekatan recycle. Warga Kelurahan Mutiara diajak memilah sampah mereka dan menukarnya dengan tabungan di Bank Sampah. Sampah yang terkumpul akan dibawa ke Pulau Jawa dengan kapal untuk didaur ulang. Program ini sempat sangat produktif dan membantu beban TPA yang jumlahnya hanya satu dan berlokasi cukup jauh dari area pemukiman pusat kota yang menghasilkan banyak sampah plastik (Asamau, 2019).

Elyas berkisah bahwa warga awalnya enggan berdekatan dengan sampah, namun karena kini bernilai ekonomis, warga tergerak mengelola sampah. Hal yang cukup menarik adalah keterlibatan anak-anak dalam penyetoran sampah setiap harinya. Elyas mengamati anak-anak sangat rajin membawa sampah setiap hari, walau harus mengantri panjang. Setidaknya 300 nasabah menjadi penabung sampah tetap (Asamau, 2019). Pada tahun 2016, program harus terhenti karena kapal tak lagi memasok sampah plastik ke Pulau Jawa. Keberhasilan Bank Sampah sebagai bentuk pemberdayaan masyarakat memperlihatkan hadirnya antusiasme warga untuk berpartisipasi dalam pengelolaan sampah saat mereka merasakan manfaat dari pengelolaan sampah yang baik.

Kegelisahan tentang sampah plastik terus mendesak beberapa warga Alor untuk segera bergerak. Pada awal tahun 2019, beberapa peneliti dari Universitas Tribuana Kalabahi bersama dengan WWF Indonesia Cabang Solor-Alor mulai membentuk PFON Alor sebagai basis penelitian dan pendataan sampah plastik (WWF Indonesia, 2019). Gerakan jejaring ini bersifat sukarela, kolektif, dan terbuka bagi publik. Dalam pelaksanaan kegiatannya, jejaring ini mengandalkan basis data online melalui website dan aplikasi ponsel pintar. Hasil dari setiap kegiatan dapat diakses oleh siapapun. Secara berkala PFON melakukan pendataan sampah di kawasan pesisir. Selain di Alor, PFON lebih dulu beroperasi di berbagai kota besar dan lokasi pariwisata pesisir di seluruh Indonesia.

Berbagai komunitas akademik, kelompok pemuda, kelompok dinas pemerintah, kelompok tentara, serta aktivis lingkungan di Alor telah bergabung dalam PFON. Jumlahnya sudah mencapai 27 kelompok (PFON Alor, 2019). PFON mengadopsi metode dari Australia dengan membagi area pantai menjadi transek-transek (Gambar 2) yang memiliki lebar 50 meter untuk didata sampahnya. Sepanjang Januari hingga Maret 2019, 8 titik pantai telah berhasil didata, yakni Pante Deere, 
Kokar, Alor Kecil, Kadelang, Pailelang, Lembur Barat, Taramana, dan Maritaing. Hasil pendataan menunjukkan $47 \%$ dari seluruh sampah berjenis plastik lunak dan $16 \%$ nya berupa plastik keras, $87 \%$ dari seluruh sampah plastik merupakan pembungkus, label makanan dan minuman, wadah makanan dan minuman, serta sedotan plastik (PFON Alor, 2019).
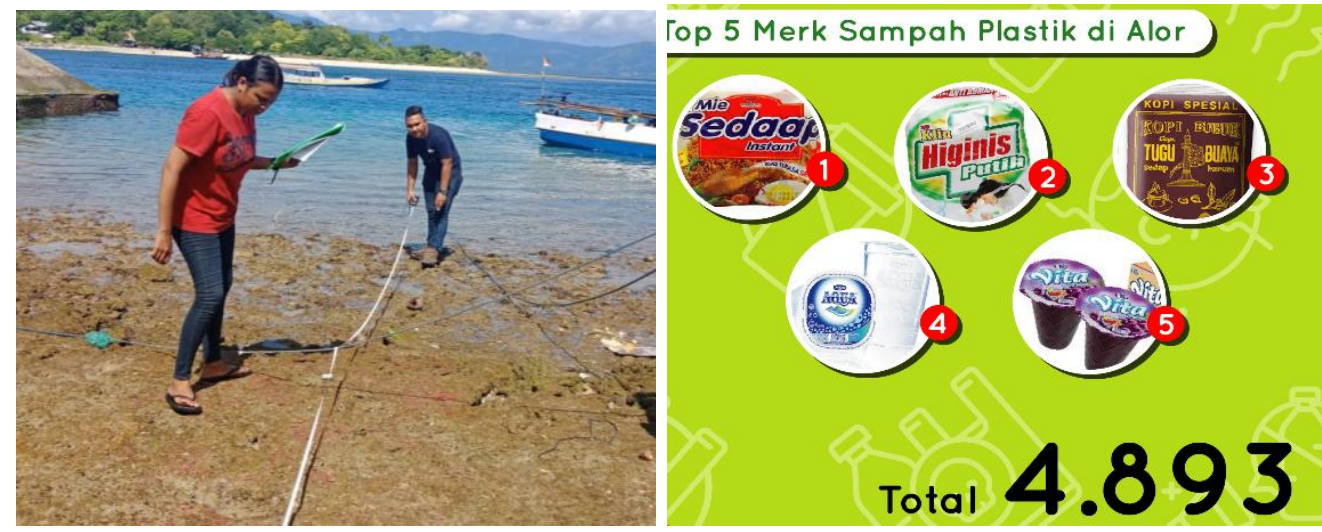

Gambar 2. Pendataan Sampah oleh PFON Alor dengan Sistem Transek \& Gambar 3. Lima Merk Sampah Plastik Terbanyak di Alor

(Sumber: PFON, 2019)

Pihak pemerintah turut menyampaikan beberapa masalah yang belum dapat diselesaikan. Satuan Kerja dari Kementrian PUPR menggarisbawahi jumlah penduduk terus meningkat, terutama di daerah pusat kota sepanjang Teluk Mutiara, yang berakibat pada peningkatan jumlah sampah (Satuan Kerja Pengembangan Sistem Penyehatan Lingkungan Pemukiman Provinsi NTT, 2018). Satuan Kerja ini juga mengeluhkan belum adanya pengelolaan sampah mandiri di tingkat desa atau kelurahan, sehingga rencananya akan dibuat sebuah tempat pembuangan sementara di sekitar Teluk Mutiara dengan konsep 3R. Selain itu, staf yang menguasai sistem pengelolaan sampah dan operator pengangkutan sampah masih minim jumlahnya. Belum lagi soal lemahnya penegakkan sanksi.

Berbagai kendala yang disampaikan pihak pemerintah ini ternyata tak menyurutkan gerilya kolektif dari para pecinta lingkungan. Mereka terus menggeliat menghasilkan progres dengan meluangkan waktu di sela-sela kesibukan harian mereka. PFON juga merilis 5 besar merk yang kemasan plastiknya paling banyak ditemukan selama pendataan sampah (Gambar 3). Daftar peringkat lokasi dengan sampah paling banyak hingga paling sedikit di 8 titik pendataan adalah Kadelang, Alor Kecil, Kokar, Maritaing, Lembur Barat, Taramana, Pante Deere, dan Pailelang.

\section{Workshop Anak: Pengenalan Lingkungan Hidup Berkelanjutan tanpa Sampah Plastik}

Saat berbincang tentang temuan PFON sepanjang awal tahun 2019, Faryda Kolly (2019) menekankan pada Tim PKM Untar bahwa area pesisir yang darurat sampah plastik berlokasi di Pantai Kadelang dan Pantai Alor Kecil. Pantai Kadelang yang berlokasi paling dekat dengan pusat Kota Kalabahi menjadi destinasi rekreasi harian warga Alor. Pemukiman warga dan garis pantai dipisahkan jalan selebar 5 meter. Rumah-rumah penduduk tersebar menghadap pantai. Pantai Kadelang juga berlokasi dekat dengan area pertokoan di Kota Kalabahi. 

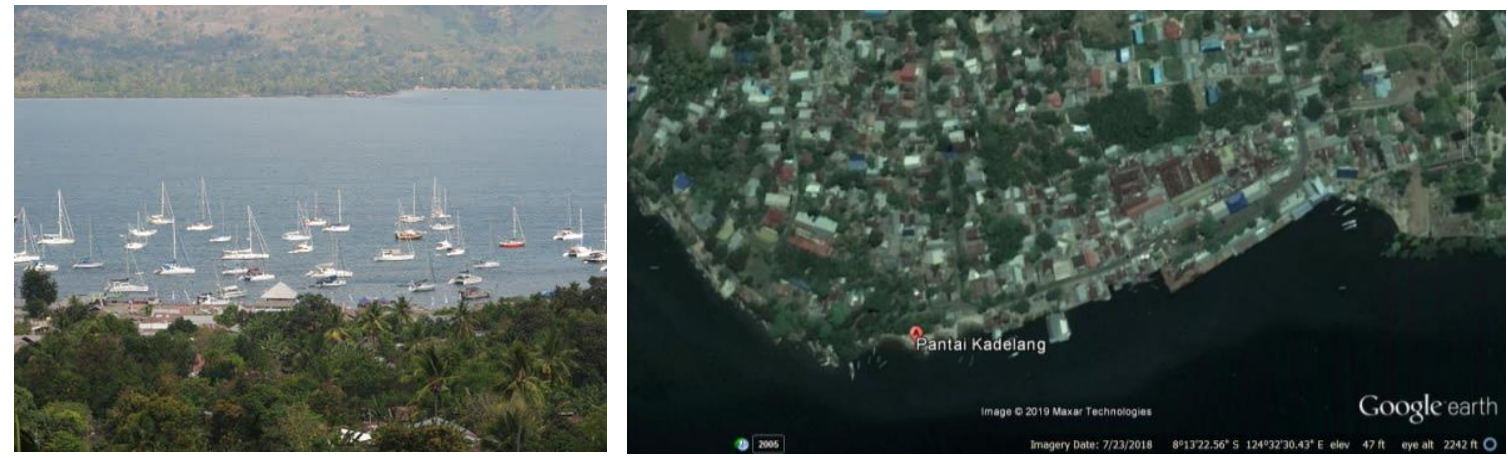

Gambar 4. Teluk Mutiara \& Gambar 5. Citra Satelit Pemukiman di Sekitar Pantai Kadelang (Sumber: Graha Budaya Indonesia, 2010 \& Google Earth, 2019)

Sementara itu, Pantai Alor Kecil merupakan titik transit menuju titik-titik penyelaman di pulaupulau di sekitar Pulau Alor. Beberapa bisnis penginapan dan penyelaman saat ini berlokasi di sepanjang pesisir Alor Kecil. Pesisi Pantai Alor Kecil langsung berbatasan dengan Selat Pantar. Di area pemukiman desa, masih dapat diamati situs-situs bersejarah yang membuktikan kedatangan berbagai kelompok etnis dari luar Alor sejak masa penjajahan Belanda, namun belum terekspos. Terdapat pula sebuah pasar dan pertokoan di sepanjang Pantai Alor Kecil.
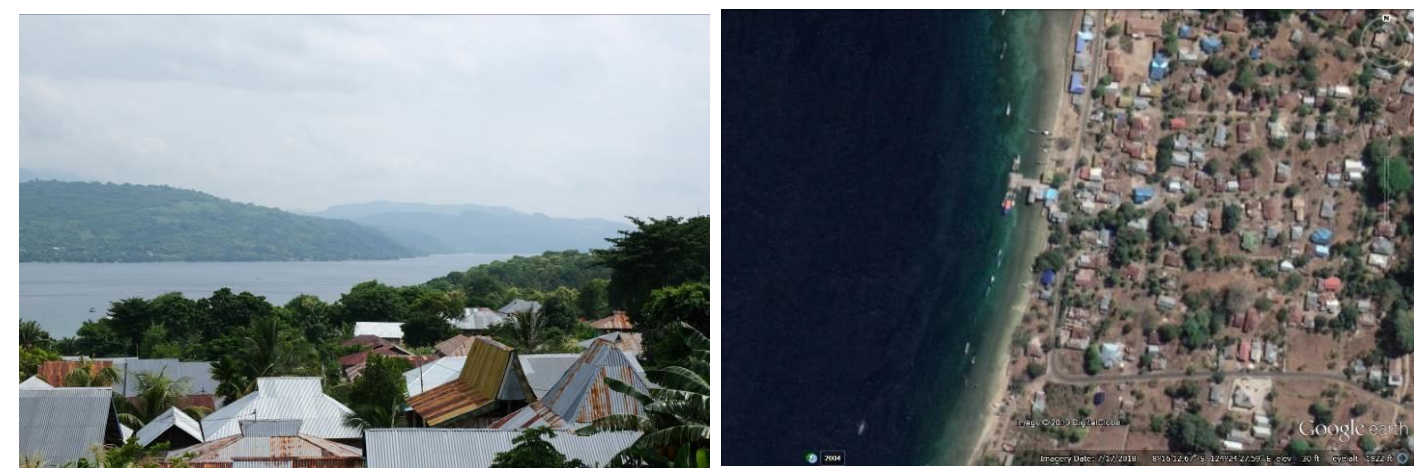

Gambar 6. Desa Alor Kecil \& Gambar 7. Citra Satelit Pemukiman di Sekitar Pantai Alor Kecil (Sumber: Antonius Tan, 2019 \& Google Earth, 2019)

Kesadaran untuk menjaga kelestarian laut dari sampah plastik pada kedua titik ini menjadi sangat kritis bila mengingat kemungkinan pembangunan infrastruktur dan fasilitas pariwisata di masa depan. Tim PKM Untar lalu menanggapi urgensi ini dengan menginisiasi program pengabdian kepada masyarakat (PKM) berupa workshop untuk anak-anak yang tinggal di kedua pantai tersebut. Workshop ini merupakan hasil kolaborasi dengan PFON Alor. Anak-anak dianggap paling tepat menjadi sasaran workshop karena mereka adalah generasi penggerak utama bagi keluarga untuk mengubah pola pengelolaan sampah. Kesadaran positif tentang kelestarian lingkungan hidup dari anak-anak di Alor juga diharapkan dapat memutus rantai ketidakpedulian dari generasi-generasi sebelumnya.

Workshop ini dibagi menjadi dua sesi, Sesi 1 berupa dongeng fabel tentang "Habitat Alorinda" dan Sesi 2 tentang pengenalan bahaya pencemaran sampah plastik ke lingkungan yang dilanjutkan dengan kompetisi pembuatan eco-brick. Eco-brick terbuat dari sampah botol plastik keras yang sudah terlebih dahulu dicuci dan potongan-potongan sampah plastik lunak yang juga sudah dicuci. Plastik lunak akan dimasukkan ke dalam botol plastik dan dipadatkan hingga menghasilkan botol 
yang cukup berat dan keras. Reuse dan Recycle sampah plastik yang menghasilkan eco-brick ini dapat digunakan sebagai material bangunan maupun untuk membuat berbagai furnitur. Hewan yang menjadi tokoh fabel adalah ayam, kambing, sapi, kucing, bebek, lumba-lumba, tikus, dugong, penyu, burung tekukur, serta ketam. Seluruh hewan ini dipilih karena mudah ditemukan di seluruh Alor. Tim penyelenggara workshop telah menyiapkan krayon, karton putih seukuran A1, serta gambar setiap hewan.
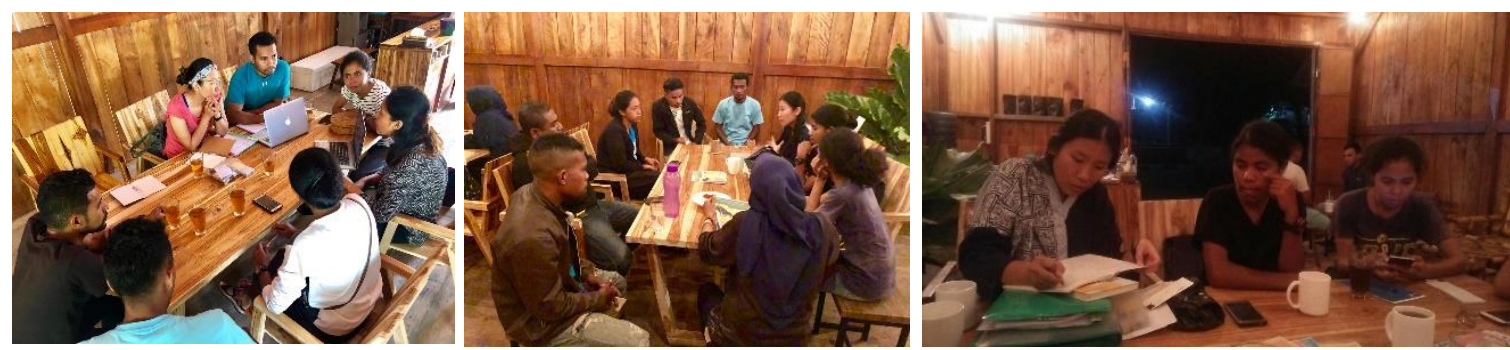

Gambar 8. Rapat Koordinasi Pelaksanaan Workshop Melibatkan Tim PKM Untar dan PFON (Sumber: Elyas Asamau \& Antonius Tan, 2019)

Pada sesi 1 ini anak-anak diminta menggambarkan secara bersama-sama kehidupan berbagai hewan darat, laut, dan udara di Alor. Gambar hewan akan ditempelkan ke karton A1 lalu di sekitar hewan tersebut akan digambar lingkungan hidup yang dapat berupa taman bunga, padang rumput, sungai, pantai, atau laut. Melalui aktivitas ini, anak-anak dapat mengimajinasikan lingkungan hidup di sekitar rumah dan menyadari kekayaan flora dan fauna di ruang hidup yang mengitarinya. Setelah aktivitas menggambar selesai, para pendongeng akan mengajak anak-anak untuk menyaksikan kisah hewan-hewan di Habitat Alorinda. Sang Burung datang mengunjungi hewanhewan sahabatnya yang pada mulanya sangat bahagia dan sehat. Namun pada kunjungan kedua, Sang Burung mendapati teman-temannya mengalami berbagai penyakit.
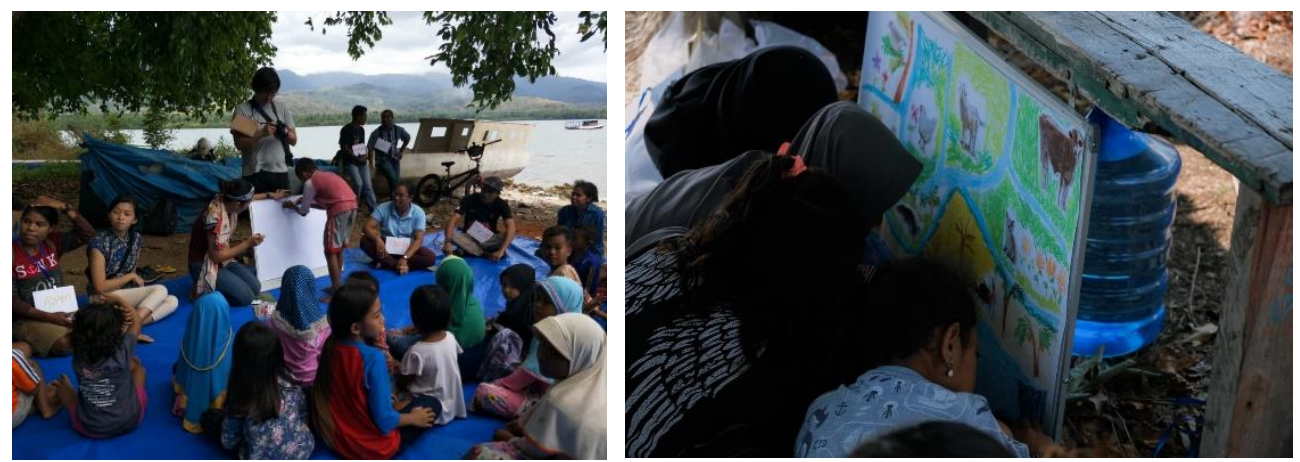

Gambar 9. Anak-Anak di Pantai Kadelang (kiri) dan Alor Kecil (kanan) sedang Menggambar (Sumber: Antonius Tan, 2019)

Ayam muntah-muntah karena tak sengaja menelan karet. Kambing gatal-gatal karena bermain di rumput yang tercemar sampah plastik. Sapi sakit perut setelah makan rumput di sekitar tumpukan sampah. Kucing demam karena minum air yang tercemar sampah plastik. Bebek sesak nafas sehabis menghirup udara terpolusi bakaran sampah plastik. Lumba-Lumba batuk karena tersedak plastik. Kepala Dugong juga terperangkap kantung plastik. Hidung Penyu tersumbat sedotan plastik. Sementara Ketam terlilit tali plastik. Situasi di Habitat Alorinda menjadi sangat menyedihkan karena penghuninya kesulitan. 

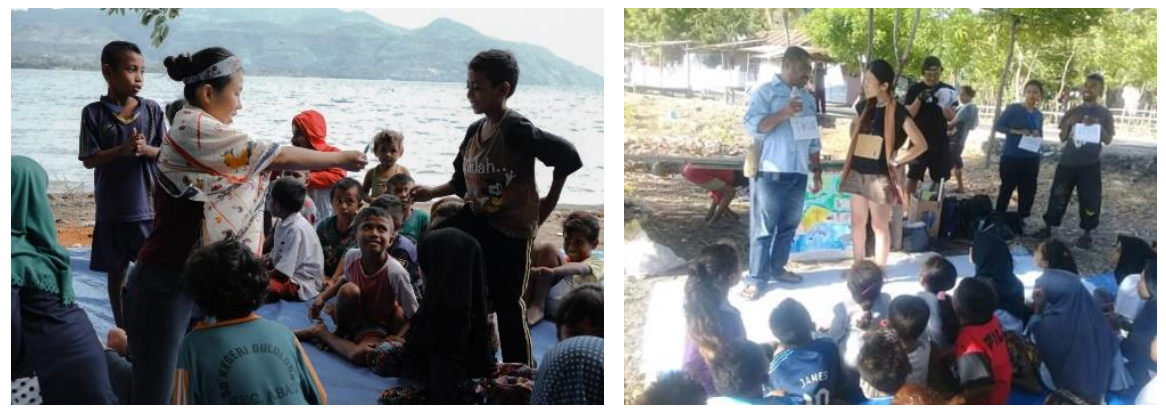

Gambar 10. Dogeng di Pantai Kadelang (kiri) dan Alor Kecil (kanan)

(Sumber: Antonius Tan, 2019)

Sang Burung berusaha mencarikan obat herbal untuk teman-temannya sambil mencari sebab merajalelanya sampah plastik. Tak lama kemudian, Burung mendapati Tikus sedang asyik menikmati berbagai kudapan dan minuman berkemasan plastik. Tikus membuang sampah plastik ke setiap tempat yang disinggahinya, ke tanah, ke rerumputan, dan ke sungai yang mengalir ke laut. Tikus juga membakar sampah plastik yang dihasilkannya. Burung prihatin dengan apa yang dilihatnya dan segera menghampiri Tikus untuk mengingatkan bahaya perilakunya sambil mengajak Tikus mencarikan obat herbal bagi teman-teman yang sakit. Saat bertemu dengan temantemannya, Tikus menyerahkan obat herbal dan meminta maaf sambil menyesali perbuatannya. Dongeng ditutup dengan habitat yang kembali sehat dan bahagia.

Sesi 1 lalu ditutup dengan kuis berhadiah tentang dongeng. Anak-anak di kedua lokasi tampak antusias menjawab untuk memburu hadiah. Mereka mampu memahami seluruh cerita dengan baik dan kini mengetahui bahwa sampah plastik yang menjadi polutan lingkungan akan mengganggu kesehatan. Baik di Pantai Kadelang maupun Pantai Alor Kecil, anak-anak yang menjadi peserta duduk di kelas 4, 5, 6, dan 7. Setelah rehat sejenak, Sesi 2 dimulai. Perwakilan PFON, Faryda Kolly dan Alexandra Waskita, menjelaskan materi tentang bahaya sampah plastik, jenis-jenis sampah plastik, dan bagaimana seharusnya sampah plastik dikelola agar tidak mencemari lingkungan. Setelah selesai dengan penjelasannya, perwakilan PFON mengajak anak-anak untuk berlomba membuat eco-brick dalam kelompok yang terdiri dari 8 orang. Di setiap lokasi workshop, peserta bisa mencapai 40 orang.

Setiap kelompok diberikan botol plastik dan potongan plastik lunak serta sebuah tongkat untuk memadatkan isi botol. Waktu yang diberikan untuk membuat eco-brick ini dibatasi selama 8 menit. Saat waktu habis, setiap kelompok harus menimbang eco-brick mereka dan kelompok yang mencatatkan total berat terbanyak adalah pemenang yang berhak atas hadiah. Anak-anak tampak mulai menumbuhkan kesadaran dan kemauan untuk menjaga lingkungan pesisir dari pencemaran sampah plastik. Mereka juga belajar memanfaatkan kembali sampah plastik menjadi eco-brick. Melalui obat herbal yang menyembuhkan hewan-hewan penghuni Habitat Alorinda, anak-anak dapat belajar berbagai manfaat dari tanaman di sekitar mereka. Peserta diminta datang ke lokasi workshop di pinggir pantai dengan membawa botol minum sendiri untuk melatih kesadaran mereka membawa alat-alat makan dan mengurangi sampah plastik.

Workshop di kedua lokasi meninggalkan kesan yang cukup mendalam bagi anak-anak dan orang tua mereka yang ikut menonton acara. Beberapa anak terlihat meneteskan air mata saat diberi hadiah karena berhasil menjawab pertanyaan tentang dongeng atau tentang pengelolaan sampah plastik. Tim penyelenggara pun semakin memahami bahwa anak-anak sangat mencintai laut dan pesisir di sekitar tempat tinggal mereka. Anak-anak meminta kepada tim penyelenggara untuk 
kembali membuat workshop serupa karena bagi mereka workshop ini memberi pengetahuan berharga dengan cara yang menyenangkan. Workshop di Pantai Kadelang berlangsung pada 11 Juni 2019 selama tiga jam dari jam 13.00-16.00 sore, sementara itu di Pantai Alor Kecil berlangsung pada 17 Juni 2019 selama tiga jam dari pukul 14.00-17.00 sore.
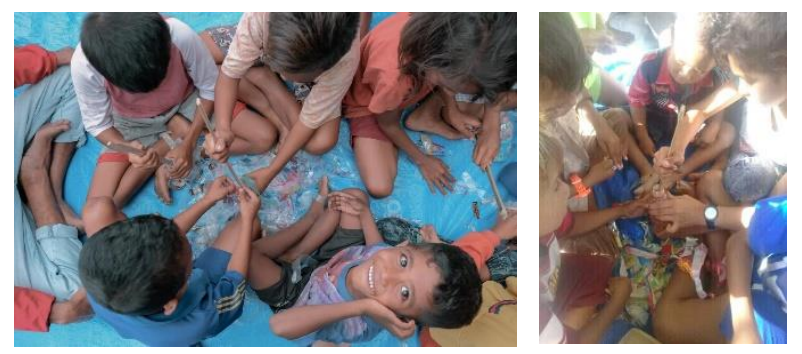

Gambar 11. Anak-Anak Membuat Eco-brick di Pantai Kadelang (kiri) dan Alor Kecil (kanan) (Sumber: Antonius Tan, 2019)

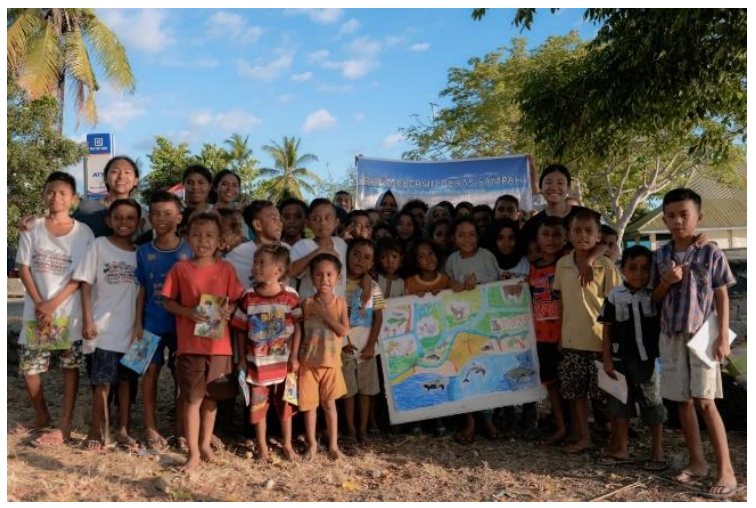

Gambar 12. Anak-Anak Peserta Workshop di Pantai Alor Kecil (Sumber: Antonius Tan, 2019)

\section{KESIMPULAN}

Kemunculan isu sampah plastik di Kabupaten Alor yang mencemari lingkungan darat dan laut belum dapat teratasi dengan pengelolaan pemerintah terhadap sampah plastik rumah tangga secara menyeluruh dan berkelanjutan. Lemahnya peraturan dan penegakan sanksi bagi publik dan pelaku usaha yang mencemari lingkungan, terutama pada titik pesisir lokasi pariwisata, tak menyurutkan tekad warga Alor yang memiliki empati besar terhadap kesejahteraan lingkungan. Dengan merefleksikan kembali ikatan historis dan kultural mereka terhadap laut dan pesisir, para aktivis ini membangun jejaring dan melakukan aksi nyata untuk mendesak perubahan. Aksi ini terus bergulir hingga pada Juni 2019, Tim PKM Untar berkesempatan berkolaborasi dalam workshop bagi anak-anak Alor yang bertujuan membuka wawasan tentang jenis dan bahaya sampah plastik, pola hidup bebas sampah plastik, penanganan serta penggunaan kembali sampah plastik. Walaupun digagas secara kolektif, sederet gerilya yang dilakukan warga Alor telah membawa progres dan optimisme bagi lestarinya alam, terutama laut Alor.

\section{Ucapan Terima Kasih}

Terwujudnya penelitian dan program Pengabdian Kepada Masyarakat di Kabupaten Alor ini berkat sponsor dari DPPM Untar serta kerjasama non-profit dengan PFON Alor. Secara khusus, 
Tim PKM Untar berterima kasih pada partisipasi dan bantuan beberapa tokoh muda Alor yang telah giat menyalakan harapan untuk alam Alor yang berkelanjutan: Elyas Asamau, Bapak Ed, Faryda Kolly, Alexandra Waskita, Selo, Elfi, Petrus, Antonius Tan, Dalton, Parto, Wany Here Wila, Denny Lalitan, dan WWF Solor-Alor.

\section{REFERENSI}

Bessie, D. M. \& Ariyogagautama, D. (2012). Penilaian Performa Pengelolaan Perikanan Menggunakan Indikator EAFM: Kajian pada Perikanan di Wilayah Kabupaten Alor. WWF \& UK Arta Wacana, Kupang.

Dinas Pariwisata Kabupaten Alor. (2016). Alor: The Hidden Underwater Paradise of East Nusa Tenggara. Dinpar Kab. Alor, Kalabahi.

Elyas Asamau. (2019, Februari). Personal Interview.

Kennedy Takalao. (2019, Juni). Personal Interview.

Kolly, Faryda. (2019). Presentasi: Pengelolaan Persampahan Kabupaten Alor Nusa Tenggara Timur. Untrib, Kalabahi.

Indonesia Sangkal Penyumbang Sampah Plastik Terbesar di Kawasan. (n.d.) 28 Januari, 2018. https://www.bbc.com/indonesia/majalah-42833138

Indrawati, Klara P. (2016). "The Sea around Alor Kecil Vernacular Society: A Critical threshold for Ecological and Cultural Survival”. ISVS E-Jurnal, Vol. 4 No. 2, 1-15.

Pengelolaan Sampah di Alor Paling Buruk di NTT. (n.d.) 12 Mei, 2018. http://tribuanapos.com/2018/05/12/ir-zet-malelak-m-si-pengelolaan-sampah-di-alor-palingburuk-di-ntt/

Plastic Free Ocean Network-Alor. (2019). Presentasi PFON Alor: April 2019. PFON, Kalabahi. Plastic Free Ocean Network-Alor. (2019). Poster: Apa Bahaya Sampah Plastik. PFON, Kalabahi Sere. (2016, Agustus). Personal Interview.

Satuan Kerja Pengembangan Sistem Penyehatan Lingkungan Pemukiman Provinsi NTT. (2018). Presentasi: Konsep Laporan Akhir Fasilitas Penyusunan PTMP dan DED Kabupaten Alor. Kementrian PUPR, Kalabahi.

Wardi, I Nyoman. (2011). "Pengelolaan Sampah Berbasis Sosial Budaya: Upaya Mengatasi Masalah Lingkungan di Bali”. Jurnal Bumi Lestari, Vol. 11 No. 1, 167-177.

Waterson, R. (1990). The Living House: An Anthropolgy of Architecture in South-East Asia. Oxford University Press, Oxford.

Willy “Air Dive". (2019, Juni). Personal Interview.

Witton, P., Elliott, M., Greenway, P. \& Jealous, V. (2003). Indonesia. Lonely Planet Publications, Oakland.

WWF Indonesia. (2019). Presentasi: Mengurangi Sampah Plastik, Mengurangi Jejak Ekologi. WWF, Semarang. 